\title{
The Value of Persistence in Elong Assimellereng As an Asset For Character Building
}

\author{
Dafirah $^{1}$, Pammuda $^{2}$ \\ \{dafirah_asad@yahoo.com\} \\ Universitas Hasanuddin
}

\begin{abstract}
Literary works have been present on this earth since time immemorial. This is the same for the Buginese people in South Sulawesi. Literary works in South Sulawesi are not only in the form of prose but are also found in the form of poetry. Poetry in Bugis society is called Elong. Elong as a reflection of Bugis society, of course, is full of and in line with the existing culture of the Bugis community. Thus, Elong is inseparable from traditions, conventions, beliefs, mindsets and even ideology. Therefore, literary works are of course full of values and meanings. One of the old poetry forms in Bugis society is elong. Etymogically, elong is defined as singing. Because elong is found in the Bugis community or in the Bugis to ugi, it is then shortened to elong ugi or elompugi. One of the elompugi that was found was elompugi assimellereng, namely elong which tells about the relationship between human beings. The research design used was descriptive qualitative. Data collection was carried out through field research and archival research, especially from the lontara manuscript archives. The research results obtained found that elong assimillereng is a poem that talks about the expression of affection for the opposite sex. This expression can mean feelings of love, anger and annoyance. Regardless the expression of feelings of love and anger because of rejection, there are actually educational values behind it.
\end{abstract}

Keywords: Persistence Value, Elong assimellereng, Character Building

\section{Introduction}

Literature is closely related to human culture, whose emergence is the result of contact between humans and the environment in which literature exists. Literature and culture according to Kustyarini includes all aspects of life that contain elements of beauty [ ]. Literature and culture in this case originated from two different terms but have a relationship with one another. Literature according to Sumardjo and Saini is an expression of the human person, which can be in the form of experiences, thoughts, feelings, and the spirit of belief in a concrete image that evokes charm by using language as a medium[ ]. On the other hand, culture is an experience in everyday life: which is contained in various texts, practices, and meanings about all people in living their lives [3,5].

Literature or literary work is an integral part of culture since time immemorial, including the Bugis who inhabit South Sulawesi. This literature has developed from time to time, even traditional / classical Bugis literature is said to have originated from the Bugis panngadereng (tradition). Based on its form, classical literature found in Bugis society consists of several types, namely folk tales, legends, fairy tales and saga[4]. In other words, it can be said that the Bugis community knows literary works in the form of prose and poetry. 
One of the old poetry forms in Bugis society is elong. Etymogically, elong is defined as singing. Because elong is found in the Bugis community or in the Bugis to ugi, it is shortened to elong ugi or elompugi. Elongmpugi/ Elong Ugi is a literary work from Bugis culture that contains beautiful words and deep meaning. In his daily life, Elong Ugi is used to subtly convey messages, wishes, and rejection to others.[6]. According to Mahmud[5] the Bugis community has various types of poetry or élong which are full of values and meanings, such as: the value of education, the value of affection, the value of courage and others. This is due to the birth of literary works that are not in a cultural vacuum but must be born in a society that already has traditions, customs, conventions, beliefs, views of life, ways of life, ways of thinking, views of aesthetics, and so on which as a whole can be categorized as a form of culture [7].

Basically, the creator of elong is unknown $(\mathrm{NN})$, but the Bugis people know and understand its existence. The origin of Elong's appearance is also not known with certainty, but Rahim[8] reveals that long ago, when there was a full moon, the children came down to the yard playing while singing, as well as the mother who was on the porch of the house, they sang along. This shows that since time immemorial, the Bugis people have been good at expressing words through elon. Based on the objectives and types, Salim [9] divides elong ugi / elompugi into several types, namely: elong assimmellereng which contains relationships between human beings; elong assiwolompolongeng contains about the relationship between husband and wife, advice; elong toto contains about fate; elong sibali contains problem solving solutions; elong madduta contains passion when proposing; elong to panrita contains religious guidance and so on.

According to Mahmud [5], the Bugis community has various types of poetry or élong which are full of values and meanings, such as: the value of education, the value of affection, the value of courage and others. This is due to the birth or emergence of definite literary works in the midst of a society that already has traditions, customs, conventions, beliefs, views of life, ways of life, ways of thinking, views of aesthetics, etc. all of which can be categorized as form of culture[7].

In this article the author only chose one of the types of elong as mentioned earlier, namely elong assimellereng. Elong assimellereng when viewed from its content and meaning, is divided into: elong mappuji, elong maccacca, elong parere, and elong mallebba [10]. Elong mappuji is a type of song that contains expressions of affection for the opposite sex or expressions of love; elong maccacca, generally tells of an expression of dislike or displeasure to the opposite sex who has expressed love or in other words, an expression of rejection; elong parere, usually contains satire aimed at the opposite sex, while elong malleba tells about expressions of feelings of anger or annoyance.

As a medium for expressing the thoughts and feelings of its creator, elong ugi / elompugi is certainly interesting to study more deeply in terms of understanding the meaning and then discovering the value it contains. In addition, elong ugi is one of the regional literary assets of South Sulawesi that enriches the national cultural treasures of the Indonesian nation.

\section{Research Methods}

Since this research is a qualitative descriptive study, so the research design used is descriptive qualitative. Basically, this method is exploratory, which is done by describing a symptom, process or condition and not based on numbers. Primary data used came from previous research that has been conducted by Muh. Salim et al[9]. In addition, primary data was 
also obtained through texts that have been collected by Jemmain [11]. The texts found in the two manuscripts were then sorted to find the type of elong assimellereng, and the value of the constancy contained therein was analyzed.

\section{Results and Discussion}

The primary data sources came from two books containing inventory, transliteration and transcription of elong ugi assimellereng text. Based on these searches, data such as the following were found:

\section{Elong assimellereng Mappuji \\ Pekkona sappa laingng \\ Engkagaro duwanna \\ Anrena matakku \\ Polena palele winru \\ Tenrekutuju mata \\ Padammu silise \\ Sagala ajak mupinra \\ tudang tengngasowokeng \\ ri laleng atikku}

\section{Elong assimellereng Maccacca}

Siduppaka nacabbiru

Iyami napuada

Sappaakolaingnge

agatokko murisengeq

tenganaaq manuq tokko

tenngamporo tokko

Mau mellek aja tona

apa takkalatoni

uwakkang lebbae

\section{Elong Assimelereng Parere}

Keganiro ri makkedanu

silere kasa rennik

pawalung taduwa

Doko mememmi polena

mewai simellereng

torannga selae

Elemani uwissengngi

\section{How do I look for another}

is there someone like her

who captivated my eyes (my heart)

I've been looking everywhere

but I found none

who is same as you

My love please don't change

sitting unmixed

inside my heart

\section{I passed hersmiling \\ nothing else she said \\ Find another one}

What are you remembered for

You're not a chicken

either a rotten egg

Eveen if love does not matter

because I already

raised a hatred

Which one you said

a piece of gauze

one shroud for us two

Suffering is the result

for loving

an aimless person

in the morning I realized 
tinrosi pale

tedong temmaddakkalae

\section{Elong assimellereng Malleqba}

Sisengngi ala massengek

nagiling sama teya

lebba mutarowe

\author{
Lebba pale teyatoni \\ dimeng paininnawa \\ ri napakku waku
}

it turns out to lead
a buffalo did not move

just reminiscing once

then turned around and did not want to

\author{
the disappointment you keep \\ the person you love \\ when treated me
}

\section{Discussion}

A tradition from the Bugis community, especially in the past, when the Bugis were still in the form of a kingdom, was singing, even read a poetry while singing at the same time. A small part of these traditions can still be found today, especially some of these forms of oral literature are preserved in the form of lontarak texts. One of the oral literature that is the object of study in this paper is oral literature in the form of elong assimellereng, an example of which has been described above.

Persistence means satisfaction with everything that has been worked on or the results obtained, loyal to belief, strong and tough instance, holding things tightly, and not breaking promises. Being strong in the Bugis language is called getting, which is obeying the principle, not changing the agreement, holding fast to your stance even though you have a new influence, which for example is more profitable ${ }^{[12]}$. The value of persistence is one or the moral values. Moral values in literature can be viewed as mandates, behaviors and messages. In fact, the element of mandate in literary works is actually a fundamental idea from the creation of literary works ${ }^{[13]}$.

Moral values must be owned by every human being, it can even become a portrait of the human soul and mind which is explored in the form of behavior or speech. Behavior and speech that in turn determine a person's dignity. Elong assimellereng is an oral literary form of the Bugis community which tells about relationships between humans or relationships that involve feelings for others. Three things were found regarding the relationship to feelings between humans, namely feelings of love, feelings of hatred, and feelings of annoyance.The Bugis community is known for its steadfast or persistence philosophy of character which makes them tend to be labeled as "strong-tempered" societies.

Whereas in fact what exists is a steadfast attitude. This is illustrated in the text elong assimellereng mappuji in the text "pekkona sappa laiinnge, crankagaro duwanna, anrena eyesakku" (how do I look for others if she is the only one, who captivates my heart). This text is an expression of someone whose love is rejected. As it is known that elong assimellereng mappuji is elong assimellereng that involves feelings of liking for fellow humans, especially the opposite sex.

The text above is an expression that shows the steadfast nature of a man who fights for his love for a woman. His love is expressed by seeing that the woman he loves is the only woman who is able to melt and captivate his heart. The text which has a similar meaning to the previous one is "polena palele winru, tenre kutuju mata, padamu silisek" (I have searched everywhere, but I have found nothing that same as you are). In this text also illustrates the steadfast attitude of a man in pouring his feelings of love, namely only to a woman. 
Besides being steadfast in fighting for his feelings of love, in the text elong assimellereng mappuji also found the value of persistence in maintaining loyalty to the opposite sex. This is as shown in the text "sagala aja mupinra, tudang tenngasowokeng, ri laleng atikku", (o my love please don't change, sit unmixed, in my heart). Loyalty to a partner is one of the manifestations of the value of constancy. It is a must to take care of the heart, take care of the eyes, and maintain the attitude for people who already have a soulmate (partner).

The attitude of loyalty in elong assimellereng parere is implied through satire words with the aim of reminding the meaning of loyalty. Faithfulness in the following text is faithfulness until death in which they will remain together.

In contrast to the previous elong species, in Bugis society there is also an elong assimellereng maccacca which describes the relationship between feelings not of affection, but on the contrary, namely dislike. This elong conveyed his feelings of dislike in an ethical way, for example, sticking with a smiling facial expression like in the text "siduppaka nacabberu, iyami napuada, sappako lainnge" (I met her and she smiled, then she said, find another one). The expression of a smile is a picture of maintaining the feelings of others, even though it is followed by a clause that expresses feelings of dislike. This text also shows the value of constancy in it, namely the determination to convey rejection to the opposite sex.

The way to express feelings of dislike is more honest in the following text: "agatokko murisengek, tennganak manu tokko, tenngamporo tokko" (for what you are remembered for, chicks not, not rotten eggs). The word agatokko denotes a phrase that shows a very firm attitude and is interpreted as an expression indicating that the other person is nobody. This text shows that it is unnecessary / pointless to remember a person who cannot do anything, or more extreme is someone who cannot help others.

The feeling of love is a feeling that arises most deeply from a person that fosters affection, a sense of beauty, a sense of always wanting to protect, a desire to always be a hero, and so on. However, it turns out that hatred / anger is able to get rid of that love. This expression can be seen in the text " Mau mellek aja tonatakkalatoni uwakkang lebbae "(Even though love doesn't matter, what's the cause I've already raised hatred).

\section{Conclusion}

Elong assimellereng is a type of oral literature belonging to the Bugis community which is a legacy from their ancestors. This elong is full of noble personality values, especially the value of persistence which the majority of the Bugis people adhere to. Elong assimellereng mappuji is also a description of the intelligence of our ancestors in the past in compiling and composing sentences that have meaning and are very beautiful and are able to touch the deepest souls when examined carefully.

Elong assimellereng is one of the literary assets of the Bugis community which is included in Indonesian literature and even world literature. The value of persistence it contains needs to be known and understood more deeply, especially by the current millennial generation. Being steadfast in acting, steadfast in thinking, being steadfast in being committed are the values needed by the generation in this millennial era. In fact, elong assimellereng can be used as a separate icon. Thus, the value of constancy contained in elong assimellereng can be used as a life principle and positive energy for the younger generation. 


\section{References}

[1] Kustyarini.2014. Sastra dan Budaya.LIKHITAPRAJNA. Jurnal Ilmiah.Fakultas Keguruan dan Ilmu Pendidikan ISSN: 1410-8771. Volume. 16, Nomor 2, hal 1-13

[2] Sumardjo Jakob \& Saini K.M. 1988. Studi Pengkajian Sastra: Perkenalan Awal Terjhadap Ilmu Sastra. Yogyakarta: Graha Ilmu

[3] Barker, Chris. 2005. Cultural Studies : Teori dan Praktik. Yogyakarta:Bentang

[4] Mattulada. 1985. Latoa, Satu Lukisan Analisis Terhadap Politik Orang Bugis-Makassar di Sulawesi Selatan. Yogyakarta: Gadjah Mada University Press.

[5] Mahmud. 1993. Kedudukan dan Fungsi Elong Ugi. Ujung Pandang: Pesantren.

[6] Mahluddin. 2017. Critical Analysis of Pappaseng's Educational Value in Elong Ugi. Thesis at the Muhamaddiyah University of Makassar.

[7] Nurgiyantoro, Burhan. 1995. Sastra Sebagai Pemahaman Antarbudaya. CakrawalaPendidikanNomor3, TahllnXIY,November .

[8] Rahman, A. rahim.1985. The Main Values of Bugis Culture. Ujung Pandang: LEPHAS.

[9] Salim, Muhammad dkk.1989. Transliterasi dan Terjemahan Elong Ugi (Kajian Naskah Bugis). Ujung Pandang: Departemen Pendidikan Nasional

[10] Nurwan, Annisa Anidya Khadijah. 2018. Telaah Strktur Teks Elong assimellereng Mappuji: Tinjauan Teori Formula Albert B. Lord. Makassar (Skripsi) .

[11] Jemmain. 1998. Elong dalam Sastra Bugis. Jakarta: Pusat Pembinaan dan Pengembangan Bahasa, Departemen Pendidikan dan Kebudayaan.

[12] Maryam. 2013. Revitalization of the Sureq Selleang Concept Analysis of the Philosophy of Earth Culture Lamaddukkelleng in an Islamic Perspective. Dissertation at Alauddin State Islamic University, Makassar.

[13] Firwan, Muhammad. 2017. Moral Values in the Novel Sang Pencerah by Akmal Nasrey Basral. Journal of Language and Literature Volume 2 No 2(2017)ISSN2302-2043 